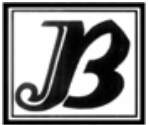

J. bio-sci. 19: 15-21, 2011

ISSN 1023-8654

http://www.banglajol.info/index.php/JBS/index

\title{
ANTAGONISTIC POTENTIALS OF TRICHODERMA SPP. AGAINST FRUIT ROT OF CUSTARD APPLE CAUSED BY PHOMA LINGAM
}

\author{
Suprakash Ojha, Manoranjan Chakraborty*, Narayan Chandra Chatterjee \\ Mycology and Plant Pathology Laboratory, Department of Botany, UGC Centre for Advanced Study, \\ The University of Burdwan, Burdwan - 713104, West Bengal, India \\ ${ }^{1}$ Department of Botany, Bankura Christian College, Bankura-722101, West Bengal, India
}

\begin{abstract}
Context: Custard-apple (Annona squamosa Linn.) is a popular tropical fruit and fruit-rot disease caused by Phoma lingam leads to considerable qualitative and quantitative damages to the fruit in the area under study.

Objective: Studies were conducted to investigate the antagonistic potential of five Trichoderma spp. namely, $T$. harzianum, $T$. hamatum, $T$. lignorum, $T$. reesei and $T$. viride against in vitro growth of the pathogen followed by field experiments.

Materials and Methods: Dual culture plate, closed petriplate and food poisoning technique were followed in order to ascertain the antagonistic potential of the five species of Trichoderma. Hyphal interaction between the pathogen and $T$. viride was studied by collecting mycelial samples from the interaction zone of dual culture plate and was processed for scanning electron microscope. Plants with infected fruits were sprayed with spore suspension of $T$. viride and two commercial bioformulations of $T$. viride viz. Trichofix and Trichoguard for three times at a dose of $0.1,0.5$ and $1.0 \%$ prepared in distilled water.
\end{abstract}

Results: All the Trichoderma species more or less effectively inhibited the growth of the pathogen through mycoparasitism, production of volatile and non-volatile metabolites. Scanning electron microscopic (SEM) micrographs revealed that hyphal interaction between $P$. lingam and $T$. viride leads to lysis of the pathogenic mycelium by the antagonist. Field experiments with spore suspension of $T$. viride and Trichofix and Trichoguard significantly reduced fruit rot incidence of custard-apple.

Conclusion: The results of the current study indicate that adoption of biocontrol based disease management programmes can be effectively utilized against similar fruit diseases.

Keywords: custard-apple, fruit rot, mycoparasitism, biological control, Trichoderma, Annona squamosa.

\section{Introduction}

Plants in their environment face potential deleterious organisms such as fungi, bacteria, viruses, nematodes, etc. and many of them are able to cause plant diseases resulting in loss of crop production worldwide. Custard-apple (Annona squamosa Linn.) belonging to the family Annonaceae is one of the best tropical fruits as it provides good carbohydrate nutrition with excellent sources of energy and minerals. The fruit pulp can be processed as frozen pulp, juice, jelly, sherbet and ice cream. Fruit rot disease of custard-apple caused by Phoma sp. is epiphytotic in the area that poses a serious threat to its production (Ojha et al. 2005). The affected plant showed blackening of the entire fruit, which gradually became hard and stony. The size of the fruits gets reduced and some shedded off from the branches.

While chemical control of plant diseases is usually expensive and may have a negative impact on the environment and on public health, the use of microorganisms to control plant pathogens, known as biological control, is accepted as a durable and eco- friendly alternative to plant disease management. Fungi have got maximum attention as antagonists probably because easy handling and identification compared to other 
microbes. In the past few years, Trichoderma spp. have received considerable attention as potential biocontrol agents for a number of plant pathogens.

Trichoderma- plant pathogen interaction suggests competition for nutrients and space (Chet 1987), inactivation of the enzymes produced by the pathogens (Ozbay and Newman 2004), modifying the environmental conditions (Benitez et al. 2004), secretion of antifungal metabolites (Dennis and Webster 1971a,b), mycoparasitism or hyperparasitism involving production of lytic enzymes (Elad et al. 1982, Lu et al. 2004), promotion of plant growth and plant defensive mechanisms leading to induced resistance in the host (Benitez et al. 2004, Ozbay and Newman 2004) and production of siderophores (Dutta et al. 2006) all of which play a significant role in the antagonism of other fungi.

Keeping these in view, the present study was undertaken to evaluate the efficacy of five Trichoderma spp. against a fruit rot pathogen Phoma lingam in terms of competition for nutrients, production of inhibitory volatile, non-volatile and soluble metabolites and hyphal interactions between the pathogen and the antagonists. Finally field trial was conducted with most effective antagonist to control the fruit rot incidence of custard-apple.

\section{Materials and Methods}

Fungal isolates: The pathogen was isolated from the infected custard-apple fruits and identified as Phoma sp. by Indian Agricultural Research Institute, New Delhi (ITCC No. 5864.04). The pathogen of the disease has now been found to be Phoma lingam. Five Trichoderma species were isolated from rhizosphere soil of different vegetable fields of Burdwan, West Bengal. All the organisms were maintained on potato dextrose agar (PDA) at $4^{\circ} \mathrm{C}$.

Evaluation of antagonistic potential of the Trichoderma spp. through mycoparasitism: Dual culture plate technique was followed in order to ascertain the antagonistic potential of the five species of Trichoderma, viz. $T$. viride, $T$. lignorum, $T$. reesei, $T$. harzianum and $T$. hamatum in terms of competition and mycoparasitism. The pathogen as well as Trichoderma spp. were grown on PDA plates for a week at $28^{\circ} \mathrm{C}$. One mycelial disc ( $5 \mathrm{~mm}$ diameter) each of the pathogen and the antagonist was placed on the surface of PDA plate at $5 \mathrm{~cm}$ apart. The inoculated plates were incubated at $28^{\circ} \mathrm{C}$ for 7 days and the inhibition of mycelial growth of the test pathogen was measured.

Evaluation of volatile compounds produced by Trichoderma spp.: In order to study the effect of volatile compounds produced by Trichoderma spp., PDA medium $(15 \mathrm{ml})$ was poured both in the base and the lid of the petriplate. The medium was allowed to solidify. Then a mycelial disc $(5 \mathrm{~mm})$ of the pathogen was placed at the centre of the lid of the petriplate and the bottom of the petriplate was inoculated with a mycelial disc (5 $\mathrm{mm}$ ) of the respective antagonist. The petriplate was sealed to one another and incubated at $28^{\circ} \mathrm{C}$ for 7 days. The percentage inhibition of growth of the pathogen was recorded as the difference in radial growth of the pathogen in the presence or absence of Trichoderma.

Evaluation of non-volatile compounds produced by Trichoderma spp.: To determine the effect of non-volatile compounds produced by Trichoderma spp. on growth of the pathogen, each of the respective antagonists was placed centrally on dialyser bag (Sigma) covered PDA plate. After 2 days of incubation at $28^{\circ} \mathrm{C}$, the respective antagonist and the dialyser bag were removed. After that, a mycelial disc $(5 \mathrm{~mm})$ of $P$. lingam was placed centrally on the same PDA plate and incubated at $28^{\circ} \mathrm{C}$ for 7 days. Growth inhibition by the respective antagonist was recorded.

Effect of soluble metabolites of Trichoderma spp. on growth of the pathogen: Food poisoning technique was adopted to study the effect of soluble metabolites of Trichoderma spp. against the pathogen. Cultures of five Trichoderma spp. were grown in $250 \mathrm{ml}$ conical flasks containing $10 \mathrm{ml}$ Czapek's synthetic broth and 
incubated at $28^{\circ} \mathrm{C}$ for 21 days. Culture filtrates were obtained by filtering through Whatman filter paper No. 1 and passed through a sterilized sintered glass filter (G-5) in order to remove the mycelial bits and spores of the antagonists. These cell free culture extracts were stored at $5^{\circ} \mathrm{C}$ for antagonistic studies.

Potato dextrose broth $(150 \mathrm{ml})$ at $\mathrm{pH} 7.2$ was taken in $250 \mathrm{ml}$ conical flasks. Soluble metabolites of each antagonist at different doses $(1,2,4,6,8$ and $10 \mathrm{ml})$ were mixed separately with the broth. An inoculum disc $(5 \mathrm{~mm})$ of $P$. lingam was placed in the conical flask and incubated at $28^{\circ} \mathrm{C}$ for 7 days. Growth inhibition of the pathogen was recorded.

Hyphal interactions through scanning electron microscope: Hyphal interaction between the pathogen and the most potent antagonist $T$. viride was studied by scanning electron microscope (SEM). Mycelial samples from the interaction zone of 15 days old dual culture plate were cut by cork borer and were processed for SEM according to Pham et al. (2005). Sodium phosphate buffer (0.1M) was prepared by dissolving $8.0 \mathrm{~g} \mathrm{NaCl}, 0.2$ $\mathrm{g} \mathrm{KCl}, 1.44 \mathrm{~g} \mathrm{Na}_{2} \mathrm{HPO}_{4}$ and $0.24 \mathrm{~g} \mathrm{KH}_{2} \mathrm{PO}_{4}$ in $800 \mathrm{ml}$ of distilled water. The $\mathrm{pH}$ was adjusted to 7.4 by $1 \mathrm{~N}$ $\mathrm{HCl}$ or $1 \mathrm{~N} \mathrm{NaOH}$ using a pH meter. The volumes were adjusted and sterilized by autoclaving. The buffer was stored at room temperature.

Glutaraldehyde solution (25\%) was prepared from the available $70 \%$ solution and was stored in refrigerator over activated charcoal. For use, the clean solution was decanted from the top and was filtered through a filter paper. After that the mycelial samples were fixed in $2.5 \%$ glutaraldehyde buffered with $0.1 \mathrm{M}$ sodium phosphate buffer at pH 7.4 for one hour. The fixed samples were washed in distilled water three times at 15 minutes intervals. The clean samples were dehydrated through a graded series of ethanol viz. $30 \%$ alcohol (5-10 min), 50\% alcohol (5-10 min), 70\% alcohol (5-10 min), 80\% alcohol (5-10 min), 95\% alcohol (5-10 min) and $100 \%$ alcohol (10-15 min with three changes).

All specimens were mounted on aluminum SEM stubs using double-sided adhesive tape. After mounting the samples were transferred to IB2 ion coater vacuum evaporation unit. The specimens were placed about 10 $\mathrm{cm}$ from the evaporation source. The samples were coated at a pressure of $10^{-5}$ torr with approximately 100 $\AA$ thick layer of gold. The coated specimens were analyzed in scanning electron microscope (S530 Hitachi, Japan) at an anode potential of $20-25 \mathrm{KV}$.

Field experiment: Field experiment was conducted at the time of fruit development in the area under study i.e. during June-July, 2010. From in vitro experiment $T$. viride was found to be most effective antagonist and thus the isolate of $T$. viride and two commercial bioformulations of $T$. viride viz. Trichofix and Trichoguard was applied at a dose of $0.1,0.5$ and $1.0 \%$ prepared in distilled water.

The spore suspension of fungal antagonist was prepared in $100 \mathrm{ml}$ distilled water using 7 days old actively growing culture of $T$. viride with the spore concentration of $10^{8} \mathrm{cfu} \mathrm{ml}^{-1}$. From this spore suspension different concentrations were prepared in distilled water. Three sprays were given for each of the treatments. First application was done prior to appearance of fruit and two subsequent applications were carried out at 10 days interval after the initiation of fruit.

Statistical analysis: There were five replications for each of the treatments. Data were analyzed statistically by one-way analysis of variance (ANOVA) and Duncan's multiple range tests using a statistical software package (SPSS 10.0 Inc.).

\section{Results}

Effect of Trichoderma spp. on growth of Phoma lingam through mycoparasitism in dual culture plate and production of volatile and non-volatile metabolites: It may be noted (Table 1) that five species of Trichoderma had been able to reduce the growth of the pathogen significantly through mycoparasitism in dual culture plate 
and production of volatile and non-volatile metabolites. A comparison between the inhibition by volatile and non-volatile metabolites of Trichoderma isolates reflects that non-volatiles were able to check the growth of the test pathogen most efficiently than the volatile ones. Highly significant reduction in pathogenic growth was observed by $T$. viride $(7.10 \mathrm{~cm})$ and $T$. harzianum $(6.64 \mathrm{~cm})$ in dual culture plate.

Table 1. Effect of Trichoderma spp. on growth of Phoma lingam through mycoparasitism and production of volatile and non-volatile metabolites

\begin{tabular}{|c|c|c|c|c|c|c|}
\hline \multirow{2}{*}{ Treatments } & \multicolumn{2}{|c|}{$\begin{array}{c}\text { Growth inhibition of the pathogen } \\
\text { through mycoparasitism }\end{array}$} & \multicolumn{2}{|c|}{$\begin{array}{l}\text { Growth inhibition of the pathogen } \\
\text { through volatile metabolites }\end{array}$} & \multicolumn{2}{|c|}{$\begin{array}{l}\text { Growth inhibition of the pathogen } \\
\text { through non-volatile metabolites }\end{array}$} \\
\hline & $\begin{array}{l}\text { Radial growth of the } \\
\text { pathogen }(\mathrm{cm})\end{array}$ & $\begin{array}{l}\text { Radial growth of the } \\
\text { antagonist }(\mathrm{cm})^{*}\end{array}$ & $\begin{array}{l}\text { Radial growth of the } \\
\text { pathogen }(\mathrm{cm})\end{array}$ & $\begin{array}{l}\text { Radial growth of the } \\
\text { antagonist }(\mathrm{cm})^{*}\end{array}$ & $\begin{array}{l}\text { Radial growth of the } \\
\text { pathogen }(\mathrm{cm})\end{array}$ & $\begin{array}{l}\text { Radial growth of the } \\
\text { antagonist }(\mathrm{cm})^{*}\end{array}$ \\
\hline T. hamatum & 3.62 & $5.38 b$ & 4.28 & $4.72 \mathrm{c}$ & 3.84 & $5.16 \mathrm{c}$ \\
\hline T. harzianum & 2.36 & 6.64ab & 3.44 & $5.56 a b$ & 2.82 & $6.18 b$ \\
\hline T.lignorum & 3.14 & $5.86 \mathrm{~b}$ & 4.08 & $4.92 \mathrm{bc}$ & 3.26 & $5.74 b c$ \\
\hline T. reesei & 3.96 & $5.04 b c$ & 4.40 & $4.60 \mathrm{c}$ & 4.06 & $4.94 \mathrm{c}$ \\
\hline T. viride & 1.90 & $7.10 a$ & 2.94 & $6.06 \mathrm{a}$ & 2.43 & $6.57 a$ \\
\hline Control & 9.00 & 0.00 & 9.00 & 0.00 & 9.00 & 0.00 \\
\hline
\end{tabular}

Table 2. Effect of soluble metabolites of Trichoderma spp. on growth of $P$. lingam following food poisoning technique in liquid medium

\begin{tabular}{lcccccc}
\hline \multirow{2}{*}{ Treatments } & \multicolumn{5}{c}{ Metabolite of } & Trichoderma spp. (ml) \\
\cline { 2 - 7 } & 1 & 2 & 4 & 6 & 8 & 10 \\
\hline T. hamatum & ${ }^{*} 141.36^{\mathrm{a}}$ & $120.98^{\mathrm{b}}$ & $92.00^{\mathrm{c}}$ & $67.68^{\mathrm{cd}}$ & $45.08^{\mathrm{d}}$ & $15.04^{\mathrm{e}}$ \\
T. harzianum & $136.98^{\mathrm{a}}$ & $116.86^{\mathrm{ab}}$ & $84.14^{\mathrm{bc}}$ & $59.22^{\mathrm{c}}$ & $23.86^{\mathrm{cd}}$ & $6.28^{\mathrm{d}}$ \\
T.lignorum & $140.40^{\mathrm{a}}$ & $121.06^{\mathrm{b}}$ & $96.18^{\mathrm{cd}}$ & $68.90^{\mathrm{d}}$ & $39.88^{\mathrm{de}}$ & $12.18^{\mathrm{e}}$ \\
T. reesei & $148.28^{\mathrm{a}}$ & $129.94^{\mathrm{bc}}$ & $105.32^{\mathrm{c}}$ & $82.18^{\mathrm{d}}$ & $49.94^{\mathrm{de}}$ & $29.04^{\mathrm{f}}$ \\
T. viride & $135.28^{\mathrm{a}}$ & $108.56^{\mathrm{ab}}$ & $74.06^{\mathrm{b}}$ & $40.16^{\mathrm{c}}$ & $9.12^{\mathrm{cd}}$ & $0.00^{\mathrm{d}}$ \\
Control & & & 156.00 & & \\
\end{tabular}

${ }^{*}$ Dry mycelial weight of the pathogen $(\mathrm{mg}) ;{ }^{* *}$ Means with the same letter are not significantly different according to Duncan's multiple range test at $\mathrm{P}<0.05$.

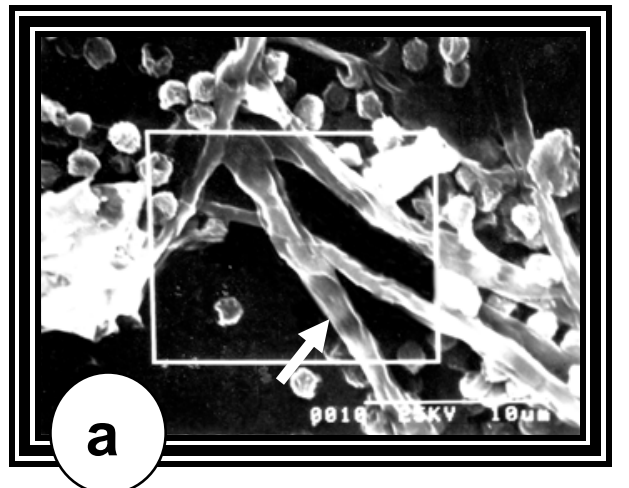

Fig 1. Scanning electron micrographs of hyphal interaction between the pathogen, $P$. lingam and the most potent antagonist, Trichoderma viride on 15 days old PDA dual culture plate. (a) Coiling of hypha of $T$. viride $(\rightarrow)$ around the hypha of $P$. lingam, (b) Formation of pore $(\rightarrow)$ on mycelium of the pathogen

Table 3. Effect of biocontrol treatments with $T$. viride isolate and two commercially available formulations of $T$. viride on development of fruit rot of cusard-apple

\begin{tabular}{|c|c|c|c|c|c|}
\hline Treatments & Rate $^{*}$ & $\begin{array}{l}\text { Total } \\
\text { no. of } \\
\text { fruits }\end{array}$ & $\begin{array}{l}\text { No. of } \\
\text { infected } \\
\text { fruit }\end{array}$ & $\begin{array}{l}\text { Percentage } \\
\text { of disease }\end{array}$ & $\begin{array}{l}\text { Percentage } \\
\text { of } \\
\text { reduction }\end{array}$ \\
\hline Control & - & 25 & 25 & 100 & - \\
\hline \multirow{3}{*}{$\begin{array}{l}\text { Trichoderma } \\
\text { viride }\end{array}$} & 0.1 & 26 & 23 & 88.46 & $11.54^{d}$ \\
\hline & 0.5 & 22 & 15 & 68.18 & $31.82^{b c}$ \\
\hline & 1.0 & 22 & 06 & 27.27 & $72.73^{a}$ \\
\hline \multirow{3}{*}{ Trichofix } & 0.1 & 23 & 18 & 78.26 & $21.74^{\mathrm{cd}}$ \\
\hline & 0.5 & 25 & 12 & 48.00 & $52.00^{b}$ \\
\hline & 1.0 & 26 & 04 & 15.38 & $84.62^{\mathrm{a}}$ \\
\hline \multirow{3}{*}{ Trichoguard } & 0.1 & 21 & 15 & 71.43 & $28.57^{d}$ \\
\hline & 0.5 & 27 & 12 & 44.44 & $55.56^{c}$ \\
\hline & 1.0 & 24 & 02 & 8.33 & $91.67^{a}$ \\
\hline
\end{tabular}
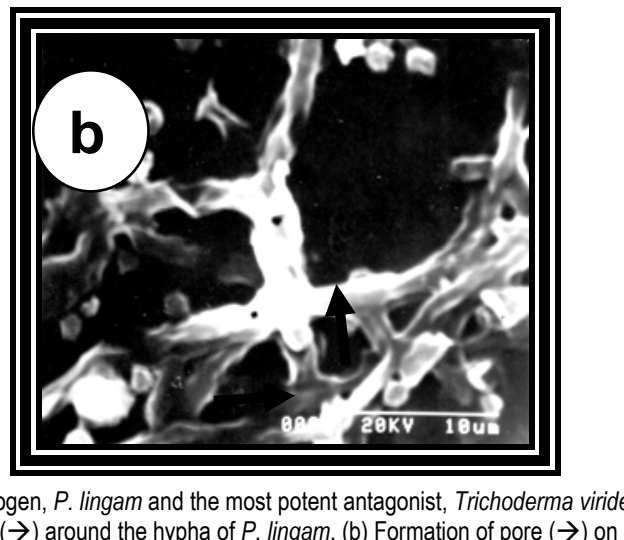

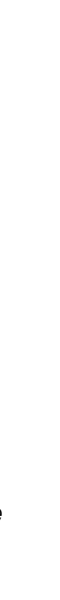


Effect of soluble metabolites of Trichoderma spp. on growth of Phoma lingam: The soluble metabolites of Trichoderma spp were able to bring about significant reduction of radial growth of $P$. lingam and with the rise in the amount of growth metabolites of the antagonists, the biomass production of the pathogen gets retarded (Table 2). Growth of the pathogen was completely arrested in treatment with $10 \mathrm{ml}$ metabolites of $T$. viride.

Hyphal interactions between T. viride and the pathogen: Scanning electron microscopic (SEM) studies of hyphal interaction between $T$. viride and the pathogen revealed that the hyphae of the antagonist underwent coiling around the hyphae of $P$. lingam (Figure 1a) followed by formation of pores on the hyphae of the pathogen (Figure 1b).

Field experiment: Plants sprayed with spore suspension of $T$. viride showed reduction in incidence of the disease up to $72.73 \%$ (Table 3). Among the two formulations of $T$. viride, Trichofix (1.0\%) exhibited $84.62 \%$ reduction in the disease and Trichoguard was observed to be most effective as it at $1.0 \%$ rate resulted in $91.67 \%$ reduction in fruit rot disease of custard- apple. In all the cases effectiveness of the treatments was enhanced with increase in their doses.

\section{Discussion}

It is apparent from the results (Table 1) that Trichoderma spp. were able to retard the growth of $P$. lingam through competition for nutrients and space and by production of volatile and non-volatile substances. According to Benitez et al. (2004) Trichoderma has a superior capacity to take up and mobilize nutrients compared to other organisms. Papavizas (1985) stated that Trichoderma spp. are often very fast growing and rapidly colonize substrates, thus excluding pathogens. The efficient use of available nutrients is based on the ability of Trichoderma to obtain ATP from the metabolism of different sugars, such as those derived from polymers wide-spread in fungal environments - cellulose, glucan and chitin among others, all of them rendering glucose (Chet et al. 1997).

It may be suggested from the result that the variation in the potentiality of Trichoderma spp. to inhibit growth of the pathogen by the volatile and non-volatile substances indicates their differential ability in production of antibiotic principle. The results were also in accordance with the findings of Bruce et al. (2000) and Kucuk and Kivanc (2003) as they reported inhibitory effect of volatile and non-volatile compounds of Trichoderma origin on several plant pathogens. In the present study, a comparison between the inhibition by volatile and non-volatile metabolites of Trichoderma isolates reflects that non-volatiles were most efficient towards growth inhibition of $P$. lingam. Vey et al. (2001) suggested that most Trichoderma strains produce several volatile and non-volatile toxic metabolites such as harzianic acid, tricholin, peptaibols, 6-pentyl- $\alpha$-pyrone, massoilactone, viridian, glioviridin, glisopenins, heptilidic acid that impede colonization by antagonizing microorganisms.

The result (Table 2) reveals that toxic metabolites, secreted in culture broth by five Trichoderma species, brought about significant reduction in vegetative growth of the pathogen and maximum inhibition was achieved with $T$. viride. Horvath et al. (1995) stated that Trichoderma isolates produce a wide range of soluble metabolites, which are inhibitory to other fungi and harzianolide is one of the important antifungal metabolites produced by Trichoderma. There is also strong evidence that the culture filtrates of Trichoderma spp. contain some kinds of antibiotics or enzymes which are involved in antifungal activity of the antagonists (Di Pierto et al. 1993).

Scanning electron micrograph clearly showed coiling of mycelium of $T$. viride around the hyphae of $P$. lingam and also formation of pore on hyphae of the pathogen. This is in concordance with other studies (Chet et al. 1981, Elad et al. 1982, Lu et al. 2004) which showed that Trichoderma coils around the hyphae of its host and then penetrates them by enzymatic digestion of the cell wall. Zaldivar et al. (2001) also recorded that 
Trichoderma species producing antifungal substances which act as mycoparasite and lyse the pathogenic hyphae. So these SEM observations indicated that coiling of the antagonist around the pathogen is an early event preceding hyphal damage. Certain chemical stimulus of pathogenic fungi may attract the antagonist and induces a chemotropic response of the antagonist. The recognition between the pathogen and the antagonist is due to lectins and this is followed by interactions between hyphae of the pathogen and the antagonist. Thus, it seems likely that hyphal interactions between these fungi are crucial in the subsequent steps leading to growth inhibition of the pathogen.

The fruit rot incidence of custard-apple was significantly reduced in response to the treatments with spore suspension and two bioformulations of $T$. viride (Table 3). Thus the isolate which showed its potential role in suppressing the in vitro growth of the pathogen, was also found to exhibit promising effect in the field condition. These results are relatively consistent with earlier studies showing the effectiveness of formulation of biocontrol agents in reducing incidence of fungal diseases of plants (Boby and Bagyaraj 2003, Khan and Sinha 2005).

Therefore, the current study provides evidence that $T$. viride shows promising antagonistic effect on the pathogen through different modes of action like mycoparasitism, production of soluble metabolites and volatile and non-volatile compounds and also by hyphal interactions. In addition, field trial with $T$. viride and its two commercially available bioformulations was also found to be significantly effective to control the fruit rot disease of custard-apple.

\section{Conclusion}

In conclusion, the present study has focused on the possibility of managing other similar fruit diseases through proper screening of the bioagents followed by their field trial and moreover, this management strategy did not pose any risk to the environment and consumer health.

\section{Acknowledgement}

Authors are thankful to Indian Agricultural Research Institute, New Delhi for identification of the pathogen. Authors also acknowledge the University Grants Commission, New Delhi for recognizing the Department as Centre for Advanced Study in Botany.

\section{References}

Benitez T, Rincon AM, Limon MC, Codon, AC. 2004. Biocontrol mechanisms of Trichoderma strains. Internat Microb 7(4), 249-260.

Boby VU, Bagyaraj DJ. 2003. Biological control of root-rot of Coleus forskohlii Briq. using microbial inoculants. World J Microb Biotech 19, 175-180. http://dx.doi.org/10.1023/A:1023238908028

Bruce A, Wheatley RE, Christien AH, Maria EJF. 2000. Production of volatile organic compounds by Trichoderma in media containing different amino acids and their effects on selected wood decay fungi. Holzforchung 54, 481-486. http://dx.doi.org/10.1515/HF.2000.081

Chet I. 1987. Trichoderma- application, mode of action, and potential as biocontrol agent of soil borne plant pathogenic fungi. In: Chet I, ed. Innovative Approaches to Plant Disease Control. New York: John Wiley \& Sons, 137-160

Chet I, Harman GE, Baker R. 1981. Trichoderma hamatum: its hyphal interactions with Rhizoctonia solani and Pythium spp. Microb Ecol 7, 29-38. http://dx.doi.org/10.1007/BF02010476

Chet I, Inbar J, Hadar I. 1997. Fungal antagonists and mycoparasites. In: Wicklow DT, Soderstrom B, ed. The Mycota IV: Environmental and Microbial Relationships. Berlin: Springer-Verlag, 165-184.

Dennis C, Webster J. 1971a. Antagonism properties of species groups of Trichoderma I. Production of non-volatile antibiotics. Trans Brit Mycol Soc 57(1), 25-39. http://dx.doi.org/10.1016/S0007-1536(71)80077-3

Dennis C, Webster J. 1971b. Antagonism properties of species groups of Trichoderma II. Production of volatile antibiotics. Trans Brit Mycol Soc 57(1), 41-48. http://dx.doi.org/10.1016/S0007-1536(71)80078-5 
Di Pierto A, Lorito M, Hayes CK, Broadway RM, Harman GE. 1993. Endochitinase from Glicladium virens: Isolation, characterization and synergistic antifungal activity in combination with gliotoxin. Phytopath 83, 308-313. http://dx.doi.org/10.1094/Phyto-83-308

Dutta S, Kundu A, Chakraborty MR, Ojha S, Chakraborty J, Chatterjee NC. 2006. Production and Optimization of Fe (III) specific ligand, the siderophore of soil inhabiting and wood rotting fungi as deterrent to plant pathogens. Acta Phytopath Entomol Hung 41(3-4), 237-248. http://dx.doi.org/10.1556/APhyt.41.2006.3-4.7

Elad Y, Chet I, Henis Y. 1982. Degradation of plant pathogenic fungi by Trichoderma harzianum. Canad J Microb 28, 719-725. http://dx.doi.org/10.1139/m82-110

Horvath EM, Buergel JL, Messner K. 1995. The production of soluble antifungal metabolites by the biocontrol fungus Trichoderma harzianum in connection with the formation of conidiospores. Mat Org 29(1), 1-14.

Khan MA, Sinha AP. 2005. Comparative antagonistic potential of some biocontrol agents against sheath blight of rice. Ind Phytopath 58(1), $41-45$.

Kucuk C, Kivanc M. 2003. Isolation of Trichoderma spp. and determination of their antifungal, biochemical and physiological features. Turk J Biol 27, 247-253.

Lu Z, Tombolini R, Woo S. 2004. In vivo study of Trichoderma - pathogen - plant interactions, using constitutive and inducible green fluorescent protein reporter systems. Appl Env Microb 70(5), 3073-3081. http://dx.doi.org/10.1128/AEM.70.5.30733081.2004. PMid:15128569 PMCid:404383

Ojha S, Chakraborty MR, Chakrabarti J, Chatterjee NC. 2005. Fruit rot of custard-apple (Annona squamosa) - a new disease from Burdwan, West Bengal. J Mycopath Res 43(1), 143-144.

Ozbay N, Newman SE. 2004. Biological control with Trichoderma spp. with emphasis on T. harzianum. Pak J Biol Sci 7(4), 478-484. http://dx.doi.org/10.3923/pjbs.2004.478.484

Papavizas GC. 1985. Trichoderma and Gliocladium: biology, ecology and potential for biocontrol. Ann Rev Phytopath 23, 23-54. http://dx.doi.org/10.1146/annurev.py.23.090185.000323

Pham GM, Srivastava A, Saxena AK, Pareek A, Varma A. 2005. Protocol to understand the interaction between rhizobacteria and symbiotic fungus. In: Podila GK, Verma A ed. Basic Research and Applications of Mycorrhizae. New Delhi: I. K. International Private Ltd.

Vey A, Hoagland RE, Butt TM. 2001. Toxic metabolites of fungal biocontrol agents. In: Butt TM, Jackson C, Magan N ed. Fungi as Biocontrol Agents: Progress, Problems and Potential. Bristol: CAB International, 311-346. http://dx.doi.org/10.1079/9780851993560.0311

Zaldivar M, Velasquez JC, Contreras I, Perez L M. 2001. Trichoderma aureoviride 7-121, a mutant with enhanced production of Iytic enzymes: its potential use in waste cellulose degradation and / or biocontrol. Electr J Biotech 4(3), 160-168ans WC. 1996. Pharmacognosy. Macmillan publishers Itd. pp 213-832. 